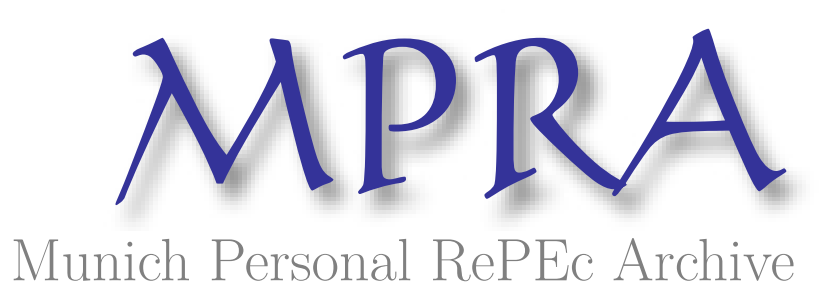

\title{
The impact of firm-type dominance on regional manufacturing growth
}

Salvary, Stanley

23 August 2007

Online at https://mpra.ub.uni-muenchen.de/12440/

MPRA Paper No. 12440, posted 07 Jan 2009 05:24 UTC 


\title{
THE IMPACT OF FIRM-TYPE DOMINANCE ON REGIONAL MANUFACTURING GROWTH
}

\author{
Stanley C. W. Salvary
}

\begin{abstract}
Availability of financial capital and location decisions are variables that influence regional manufacturing output. This study maintains that a region's manufacturing growth depends upon the region's firm-type dominance. That is, the type of firms that dominate the region's manufacturing output can be classified as non-local (national or foreign - NF) vs. local and large vs. small. Accordingly, for policy analysis, regions can be classified by firm-type dominance. This distinction is important since, invariably, location decision options and availability of financial capital are more favourable for the larger NF firms than for local firms. In an attempt to assess the impact of firm-type dominance, this study draws upon the dominant industry model [Salvary 1987] which has established that, in any given region, there is a dominant industry (the driving force of the region) to which a region's manufacturing growth is linked. The information on the impact of firm-type dominance on a region's manufacturing output may enable policy-makers to design workable (or revise existing) manufacturing diversification policies.
\end{abstract}

\section{INTRODUCTION}

The loss of jobs due to the relocation or liquidation of firms is the chief cause of a region's economic instability. Based upon a briefing report prepared by the US General Accounting Office, between 1979 and 1984, approximately 2.3 million US workers annually were dislocated. This dislocation occurred primarily due to layoffs and plant closures in the manufacturing sector [Stafford 1991:51]. Since manufacturing firms' location decisions have been a major contributing factor accounting for regional economic instability, the seemingly logical solution is for a region to develop a diversification policy (using portfolio theory) to attract manufacturing firms into the region in such a manner as to create a diversified regional manufacturing structure. According to Grose [1993:23], in the early 1980s, total states' incentives in the form of direct outlays and taxes foregone to attract business amounted to $\$ 20$ billion a year. Indubitably, a diversification policy, that would attract a mix of manufacturing firms to ensure long term regional economic stability or at least to minimize severe long term instability, is highly desirable.

As suggested by Conroy [1975], portfolio theory is a means to diversify away economic instability as reflected in a region's rate of unemployment. Empirical findings on the New England region of the US indicate some success with a diversification policy [Rosengren 1990]. Using portfolio variance analysis, Rosengren [1990] was able to establish that New England had 
been able to attract a good mix of industries in its employment portfolio. During 1984-1988, unemployment in New England was $3.9 \%$ on average as compared to the national average of 6.7\%. However, cuts in defense spending and competition from outside the region had eroded some of that success [Rosengren 1990]. Data accumulated by Grose [1993:27] revealed that six of the New England states are ranked among the bottom ten states in: (a) 1991 for "New and Expanded Corporate Facilities by State" (per million population), and (b) "State Economic Momentum" given "State Business Incentives" at March 1992.

This study suggests that, with the aid of a firm-type dominance/industry region analysis, state and federal levels of government can formulate productive regional economic policies.

\section{RESEARCH OBJECTIVE}

In an empirical study [Salvary 1977], it was established that while manufacturing growth of a region is significantly related to the growth of the region's dominant industry, leakage of manufacturing growth/output from the region is attributed to the inability of the region's supportive industries to respond to the growth of the dominant industry. This study postulates that firm-type dominance of regional manufacturing provides an explanation for regional leakage of manufacturing output.

With the foregoing in mind, this research presents and tests a working hypothesis - the firm-type dominance of regional manufacturing growth. The findings on firm-type dominance can enable an assessment of the feasibility of particular strategies to combat regional instability. In particular, this research attempts to enable an assessment of a region's ability to utilize the intuitively appealing strategy of portfolio theory [Conroy 1975] in selecting and attracting manufacturing firms.

Whether the firms desired to be attracted into the region are labour intensive or capital intensive, an approach to enhance or stabilize a regional manufacturing output is needed. As suggested by Ersenkal and Dillman [1984:38], if policymakers were to recognize that an abundance of a particular industry is not desirable, an attempt should be made to alter some aspects of the regional characteristics that could stimulate growth in [or attract] industries dependent upon factors which have not been sufficiently developed. 
The basic question is: Can diversification policy be effectively implemented by a region? Data presented by Grose [1993:27] suggest an ambiguous response. Some states (e.g., North Carolina, Nevada, and Wyoming) with fewer incentives to attract business firms have done better than many states with far more incentives. It is important to note that tax wars among states competing for the same industries [Committee of New England of the National Planning Association 1954:651] can impede the implementation of such a policy. While it is likely for regions to effectively utilize diversification policy, it would be somewhat difficult in the absence of coordinated planning by state and federal policymakers.

Unmistakably, regional economic development is dependent upon a region's ability to devise means to influence location decisions of individual firms and the flow of financial capital into the region [Salvary 2004]. This study maintains that the impact of these factors on any region is determined to a great extent by the firm-type dominance of a region as opposed to the industrial structure/mix of a region. Hence, the feasibility of a diversification policy hinges on the adherence of policymakers to policies consistent with the specific region's firm-type dominance.

\section{MINIMALLY NECESSARY CONDITIONS FOR DIVERSIFICATION}

Based upon their empirical study, Bremmer and Kesselring [1993:14] concluded that education and public goods provided by state governments do have a positive impact on investment and economic development. The availability of these public goods attracts new firms to a given location and facilitates continued operations of existing firms, but attempts to entice new firms with items such as industrial revenue bonds and equipment tax credits are ineffective.

This study postulates that to achieve an effective diversification policy, three conditions must be satisfied: (1) incentives must be specifically designed to induce the desired mix of manufacturing firms; (2) an infrastructure, which is conducive to the operations of the desired mix of firms, must be built and maintained; and (3) the industrial climate must be nurtured by the availability of financial capital and an adequately trained labour force. The ability to satisfy these three conditions would enhance the ability of the region to attract and retain manufacturing firms. Apparently, the findings of Coughlin and Segev (2000:346), which included labour force quality and transportation infrastructure, in part do support the three conditions outlined above. 
Unequivocally, tax wars among states competing for the same industries have to be avoided. Therefore, cooperation and coordination of effort among the federal and state levels of governments are essential to the regional success of a diversification policy. At this stage, the concepts of the state regions and the industry regions are introduced.

\section{STATE REGIONS AND INDUSTRY REGIONS}

Some studies [Carlton 1983; McHone 1984] use the Standard Metropolitan Statistical Area (SMSA) as the region, while other studies [Helms 1985; Steinnes 1984] use the state as the region. In this study, two types of regions are used: state-regions and industry-regions. A stateregion is a region in physical space linked by a common administrative unit which influences economic development. An industry-region is a region in economic space linked by a common dominant industry which influences regional manufacturing growth [Salvary 1977].

Gertler [1984:74] posed two questions: (A) "How volatile is investment in a given industry in a given place over time?" (B) "How consistent is this volatility from region to region?" With regards to (A), the state-region permits an analysis of the volatility of financial capital flows. In connection with (B), the industry-region (a different dimension to regional analysis) enables an assessment of the consistency in the volatility of regional financial capital flows.

As indicated above, this study uses the state as the basic region. 1 The state is chosen as the basic region in this study for three reasons:

1. Unemployment insurance is administered at the state level.

2. The level and type of tax and other incentives necessary to undertake a diversification policy can only be undertaken at the state level.

3. Infrastructure building, such as highways, conducive to the healthy economic climate is undertaken primarily at the state level.

Apart from the normal response to market forces--internal economies of scale and agglomeration--that affect the location decision problem, some regions grow faster than others due to greater capital inputs into the state regions. The disparity in regional growth may be due to a greater rate of investment or greater capital input-output ratio for the faster growing regions. It is hypothesized that a stagnant region may have funds that are exported to another growing 
region, in many instances to a region that is much more developed--the backwash effect [Myrdal 1957]. This condition would obtain since the mix of the firms in a region (local vs national firms) - the firm-type dominance hypothesis - influences the flow of capital in and from the region. Accordingly, the next section addresses the issue of the availability of financial capital the capital availability problem.

\section{THE AVAILABILITY OF FINANCIAL CAPITAL}

Invariably, firms obtain their financing from the national pool of investment funds [Salvary 2004]. Yet, all firms do not get their efficient share of the investment pool (the capital availability problem). Large firms through corporate dividend policy escape the capital market rationing process; hence, more efficient smaller firms are denied financing for expansion purposes. Corporate earnings retention as the primary source of finance for manufacturing capital expenditures is an ongoing trend [Rumelt 1974; Sherman 1968; Brittain 1966; Donaldson 1961; Cottle and Whitman 1959; Meyer and Kuh 1959; Drobovolsky 1951; Lintner 1949]. Use of internally generated funds significantly affects the rationing of financial capital because this financing is only minimally subject to the scrutiny of the capital market [Rumelt 1974:155; Donaldson 1961:51-52].

Kalecki [1954:92-95] and Hamberg [1956:34] have clearly emphasized the significance of capital availability in the investment decision and the inaccessibility of the capital market to small firms. In this regard, Fotheringham [1985] (1) implicitly recognized the need to determine the characteristics of the firms making the location decisions, and (2) proposed that an explanation of regional growth should entail a modeling of the decision processes of individual firms. Therefore, foreign direct investment in US manufacturing is a factor that has to be considered.

According to Stafford [1991:51]: "Although there is now a substantial literature on plant closings, knowledge and theory still lag behind understandings of manufacturing investments and the location of new plants." Like the core-periphery dichotomy to regional growth (the spread effect and backwash), the firm-type dominance/industry region approach attempts to explain regional growth variation (the responsiveness effect). At this stage, the dominant industry hypothesis is introduced and the firm-type dominance hypothesis of regional manufacturing growth, which reflects an integrated approach, is formulated. 2 


\section{THE DOMINANT INDUSTRY AND FIRM-TYPE DOMINANCE HYPOTHESES}

This study utilizes the concept of the dominant industry as introduced in the literature as a causal factor [Salvary 1977]. An industry which accounts for $10 \%$ or more of a region's manufacturing value added is a dominant industry. If that industry has not only met the $10 \%$ requirement but is the largest single industry in the region, it is the dominant industry. "The role of the dominant industry in regional manufacturing growth is a passive one, in that it is subsumed under the caption of comparative advantage or industrial structure" [Salvary 1977:2]. The dominant industry analytical approach was advanced in response to the criticism levelled at shiftshare analysis: "There can be no question that the degree and structure of past industrial activity in a region will, . . . have a major influence on the degree and structure of future industrial activity, but the magnitude and statistical significance of this influence could be one of the objects of research, not one of the assumptions of research" [Burrows, et. al. 1971:16].

The concept of "growth poles" [Perroux (1955)1970] focuses on growth manifesting itself at points or poles of growth with variable intensity spreading through different channels with terminal effects on the whole economy. Whereas, the dominant industry hypothesis [Salvary [1977:4-5], maintains that the dominant industry in a region is the industry which best responds to the forces at play; as a result, this industry becomes the moving force of the region. The growth of the region is then conditioned by the responsiveness of the supporting industries and consequentially the industrial structure of the region emerges as a consequence.

The dominant industry hypothesis rests upon the following assumptions:

(1) The division of the economy into productive sectors: agricultural, industry, and service.

(2) The industry sector is comprised of $m$ industries, which are contained in the finite set $F$. $\mathrm{F}=\mid \mathrm{f} / \mathrm{f}_{1}, \mathrm{f}_{\mathrm{c}}, \ldots, \mathrm{f}_{\mathrm{m}} \mathrm{l}$. These $\mathrm{m}$ industries are dispersed over $\mathrm{k}$ regions; however, $\mathrm{f}_{1}$ (and every $f$ ) is dispersed over $n$ regions, where $n<k$.

(3) The output demand of $f_{1}$ (as well as $f_{2}, \ldots f_{m}$ ) is not evenly distributed among the $k$ regions. Also, there is a difference in the intensity of demand for final and intermediate consumption of the $\mathrm{m}$ industries.

(4) The transportation needs of the $m$ industries differ, and the transportation networks differ among the $\mathrm{k}$ regions. ${ }^{3}$ 
(5) The availability of financial capital differs among the m industries and among the $\mathrm{k}$ regions. The manner in which capital is made available reflects an industry capital preference with significant regional impact.

The basic assumptions insinuate that the concept of the dominant industry brings together the demand and supply determinants of regional economic expansion. The dominant industry emerges in a region when: (i) there is a sustained increase in regional demand for an industry's output, (ii) the region's capital investment preference favours that industry, and (iii) the transportation network which services the region is capable of handling the increase without a significant increase in cost [Salvary 1987:77-78]. In any given time period, any of several industries are potential candidates for becoming a dominant industry in a region. Which industry actually becomes the or a dominant industry is dependent upon: (a) the regional capital investment preference, (b) the degree of capital saturation, and (c) the industry's degree of dependence on and the intensity of use of the transportation network [Salvary 1987:78].

Concomitant with the development of the dominant industry is the emergence of the industry region: a region in economic space linked together by a common dominant industry [Salvary 1977:19]. Industry regions (e.g., chemical, etc.) were introduced to provide a means for observing the impact of the dominant industries within an idealized spatial context. The industry region approach is a controlled observational approach [Salvary 1987:79].

The firm-type dominance hypothesis of regional manufacturing growth (RMG) as developed in this paper, which should have significant explanatory power, is expounded as follows.

A region's manufacturing output and development is conditioned by:

1. the size (measured by sales) of firms operating in the region $\left(\mathbf{F}_{\mathbf{S}}\right)$;

2. the multiplier effect (elasticity) of the region's dominant industry $\left(\mathbf{D I} \mathbf{I}_{\mathbf{m}}\right)$, and

3. the location choice options facing the firms ( $\mathbf{F}_{\mathbf{t}}$ : firm-type--national vs. local firms).

Equation 1 is the mathematical formulation of the hypothesis:

$$
\mathbf{R M G}=\mathrm{f}\left(\mathbf{F}_{\mathbf{s}}, \mathbf{D I}_{\mathbf{m}}, \mathbf{F}_{\mathbf{t}}\right) \text {. }
$$

In this working hypothesis, firm-type dominance maintains that a region's manufacturing output is dominated by either national/foreign or local firms. The firm-type dominance 
hypothesis postulates that if a region's manufacturing output is dominated by local firms, its strategic posture is entirely different from that of a region dominated by national/foreign (N/F) firms. The financial capital and the location decision options available to the large N/F firms are more favourable than those of the comparatively small local firms. In particular, the larger N/F firms can ensure, by means of a significant earnings retention policy, a greater share of capital to satisfy its financial needs [Rumelt 1974:155; Brittain 1966:155]. Thus, financial capital is endogenous to the "N/F firm dominated" regional model; whereas, it is an exogenous variable to the "local firm dominated" regional model. Simply understood, in many instances capital is simply not available to the invariably smaller local firms [Hamberg 1971:32-34; U.S. Congress 1971:1465]. Also, the location decision options are many for the large firms already operating through several branch plants; 3 whereas, the options are quite few for the local firms.

\section{FIRM-TYPE DOMINANCE AND REGIONAL MANUFACTURING GROWTH}

As developed by Salvary [1977], an industry region construct (a region in economic space consisting of sub-regions having the same dominant industry), which enables the observation of the varying response patterns to the dominant industry, is used in this study. The responsiveness of a region's supportive industries to the growth of the region's dominant industry is measured by means of the coefficient of elasticity. Low responsiveness of the supportive industries can be attributed to either: (a) the unavailability of financial capital (local firm-type dominance) or (b) the external (out of region) location decision of the supportive industries' expansion (national/local firm-type dominance) [Salvary [1977:115,122,130].

State economies are interdependent parts of the national economy and forces outside each state do impinge upon the stability of employment in a state [Engerman 1965:325]. As noted by Coughlin and Segev [2000:323-322]: “[A]n increasing share of manufacturing production in the United States is taking place under foreign rather US ownership. In fact, despite the decline in manufacturing employment since 1979, manufacturing employment in foreign-owned firms more than doubled between 1979 and 1995. . . . Given the rising share of foreign enterprises in US manufacturing activity, the location of new foreign-owned plants is a significant determinant of the geographic distribution of manufacturing employment." 
Hence, the firm-type dominance hypothesis of regional manufacturing growth should be significant to policy-makers at the state and national level. This working hypothesis postulates a relationship between a state's industrial structure and the variation in the impact of the dominant industry within an industry region. Assuming that industrial diversification via portfolio theory would necessitate a selective state tax incentive strategy, apart from inducing tax wars among the states [Business Week 1976:92] such a strategy more likely would be ineffective due to the minor importance of tax in context of total business operating costs. The Committee of New England of the National Planning Association [1954:645] made it quite clear that in some instances taxation may be the marginal element that can influence the decision in a region's favour. It was emphasized that taxes are a small percentage of costs in almost all industries. Since all costs are seldom equal, it is most unlikely that the absolute differences in tax costs will be significant enough to overcome the differences in other costs which constitute a larger proportion of total costs. Invariably, to the firms, the important determinants in industrial location, both within and among regions are the small differences in those costs which are a large proportion of total costs.

\section{DATA，METHODOLOGY, AND ANALYSIS}

Data were collected on: (a) plant manufacturing locations [Marketing Economics Key Plants 1960;1969/70;1980/81]; (b) location of corporate headquarters and firm size in sales [Million Dollar Directory 1964,1971,1980,1987]; and (c) manufacturing value added and employees [Census of Manufactures 1963;1967;1972;1977;1982;1987;1992. Annual Survey of Manufactures 1959-60;1961;1962;1964-65;1968-69;1970-71;1988-1991;1993-1996]. Measures of elasticity (responsiveness of supportive industries to growth of dominant industry) for regions/states comprising three industry regions (1960-1971) were obtained from Salvary [1977:113,122,130].

To associate changes with specific identifiable phenomena or emerging traits and to enable the impact of small firms to be observable in the amassed data, large firms are defined as firms with annual sales volume of $\$ 100,000,000$ or more. Table 1 presents the elasticity estimates/response coefficients of the regions' total manufacturing value added growth rates to the regions' dominant industry growth rates and changes in manufacturing employment for the states comprising the chemical (SICC28), electrical (SICC36), and food (SICC20) industry regions. 
In Table 1, two groups - a high response group (HRG) and a low response group (LRG) are identifiable. The HRG consists of: Chemical industry region - Tennessee, Texas, Virginia, and South Carolina; Electrical industry region - Illinois, Connecticut, and Kentucky; and Food industry region - Missouri, Georgia, and Minnesota. The LRG consists of: Chemical industry region - Alabama, West Virginia, Louisiana, and New Jersey; Electrical industry region - New Hampshire, Indiana, California, and Massachusetts; and Food industry region - Florida, Iowa, Wisconsin, and Colorado. This partitioning is necessary in order to determine the firm-size (large or small firms) that dominated the manufacturing activities of the high and low response groups.

Changes in Table 1 reveal that the more significant changes occurred in the chemical industry region. However, the general information pertaining to firm-type dominance can be extracted when comparing the data for 1970 with that of 1980 . The relative changes in manufacturing employees for 1980 can be a guide for policy prescription.

Feiock and Rowland [1990] in an empirical study concluded that environmental regulation (i.e, the cost of pollution abatement) influences interstate allocation of investments in the chemical industry. Hence, variations in state laws on environmental protection would influence location decisions. Given the foregoing, the firm-type dominance hypothesis has added significance due to the fact that the non-local (national or foreign - N/F) firm has greater latitude in its location choice decision than does the local firm. Since (Table 1) the more significant changes occurred in the chemical industry region, that region is chosen to assess the expected impact of regional firm-type dominance on regional manufacturing output.

Apart from pollution abatement cost, other factors do contribute to restructuring in the various state-regions. One factor is the relationship between international trade and regional economic change. As noted by Bauer and Eberts [1990:39-40], during the 1980s, apart from a decline in manufacturing employment in the national economy, there has been a significant structural shift in (1) the location of manufacturing across states and (2) the composition of manufacturing within states. Those researchers maintain that the expansion of international trade can have a significant impact on domestic regional economies. Being in direct competition with domestic manufacturers, foreign imports can decrease domestic production by displacing domestic output. Therefore, foreign imports have to be seriously considered in all policy analysis. 
TABLE 1

TOTAL \& INDUSTRY SPECIFIC MANUFACTURING VALUE ADDED GROWTH RATES FOR 1960-1971, REGIONAL ELASTICITIES, AND MANUFACTURING EMPLOYEES

\begin{tabular}{|c|c|c|c|c|c|c|c|c|}
\hline \multirow[b]{5}{*}{ State/Region } & \multicolumn{7}{|c|}{ PANEL A: CHEMICAL INDUSTRY } & \multirow[b]{2}{*}{ Manufacturing } \\
\hline & \multicolumn{2}{|c|}{ Exponential } & & \multicolumn{4}{|c|}{ Manufacturing } & \\
\hline & \multicolumn{2}{|c|}{ Growth } & Elasticity/ & \multicolumn{4}{|c|}{ Employees $(000)$} & \multirow{2}{*}{ Employees } \\
\hline & \multicolumn{2}{|c|}{ Rate For MVA } & Response & \multicolumn{2}{|c|}{1970} & \multicolumn{2}{|l|}{1980} & \\
\hline & $\underline{\mathrm{T}}$ & $\underline{\mathrm{C}}$ & Coefficient & & & $\mathrm{T}$ & & $\underline{\mathrm{T}} \quad \underline{\mathrm{C}}$ \\
\hline Tennessee & 8.5 & $\overline{9.3}$ & 0.8816 & $\overline{448}$ & $\overline{54}$ & $\overline{491} 5$ & & $(\overline{3.7})$ \\
\hline Texas & 7.8 & 9.3 & 0.6621 & 722 & 54 & 10467 & & 44.8 \\
\hline Alabama* & 7.6 & 16.5 & 0.4007 & 305 & 12 & 349 & & 14.1 \\
\hline South Carolina* & 7.6 & 10.6 & 0.5674 & 324 & 24 & 3913 & & 20.7 \\
\hline Louisiana & 7.1 & 13.3 & 0.3871 & 168 & 22 & $209 ?$ & & 24.4 \\
\hline Virginia & 5.9 & 6.5 & 0.6652 & 354 & 38 & 4183 & & 18.1 \\
\hline New Jersey & 3.3 & 9.7 & 0.3654 & 8591 & 02 & 814 & & $(5.2) \quad(5.9)$ \\
\hline West Virginia & 2.8 & 5.0 & 0.5014 & 122 & 23 & 115 & & $(5.7) \quad(65.2)$ \\
\hline \multicolumn{9}{|c|}{ * Chemical industry is the second most important industry but not the dominant industry. $\mathrm{T}=$ Total Manufacturing $\mathrm{C}=\mathrm{Chemical}$ Manufacturing } \\
\hline \multicolumn{9}{|c|}{ PANEL B: ELECTRICAL INDUSTRY } \\
\hline & \multicolumn{2}{|c|}{ Exponential } & & \multicolumn{4}{|c|}{ Manufacturing } & Manufacturing \\
\hline & \multicolumn{2}{|c|}{ Growth } & Elasticity/ & \multicolumn{4}{|c|}{ Employees $(000)$} & $\underline{\text { Employees }}$ \\
\hline & \multicolumn{2}{|c|}{ Rate For MVA } & Response & \multicolumn{2}{|c|}{1970} & \multicolumn{2}{|c|}{1980} & $\%$ Change \\
\hline State & $\underline{T}$ & $\underline{E}$ & Coefficient & $\underline{T}$ & $\underline{E}$ & $\underline{\mathrm{T}}$ & $\underline{E}$ & $\underline{\mathrm{T}} \quad \underline{\mathrm{E}}$ \\
\hline$\overline{\text { Kentucky* }}$ & $8 . \overline{3}$ & $14 \overline{1}$ & 0.5380 & $1 \overline{6} 8$ & $\overline{33}$ & $\overline{209}$ & $\overline{32}$ & $(\overline{3} .0)$ \\
\hline California* & 5.2 & 9.5 & 0.3966 & 1568 & 205 & 2075 & 317 & $32.3 \quad 54.6$ \\
\hline New Hampshire & 4.8 & 9.5 & 0.4982 & 92 & 17 & 107 & 17 & 16.3 \\
\hline Indiana & 4.8 & 8.7 & 0.4873 & 713 & 111 & 654 & 103 & $(8.3)$ \\
\hline Illinois* & 4.3 & 6.5 & 0.7300 & 1344 & 186 & 1272 & 159 & $(5.4)$ \\
\hline Connecticut* & 3.6 & 5.4 & 0.7149 & 446 & 45 & 463 & 47 & 3.8 \\
\hline Massachusetts & 2.7 & 5.5 & 0.3320 & 640 & 97 & 694 & 95 & $8.4 \quad(2.0)$ \\
\hline \multicolumn{9}{|c|}{ * Electrical industry is the second most important industry but not the dominant industry. $\mathrm{T}=$ Total Manufacturing $\mathrm{E}=$ Electrical Manufacturing } \\
\hline \multicolumn{9}{|c|}{ PANEL C: FOOD INDUSTRY } \\
\hline & Expor & ential & & & Manu & facturing & & Manufacturing \\
\hline & Gro & wth & Elasticity/ & & Emplo & jees $(000$ & & Employees \\
\hline & Rate Fo & r MVA & Response & & 970 & & & $\%$ Change \\
\hline State & $\underline{T}$ & F & Coefficient & $\underline{T}$ & F & $\mathrm{T}$ & $\underline{F}$ & $\underline{\mathrm{T}} \quad \underline{\mathrm{F}}$ \\
\hline Florida & 9.1 & 10.2 & 0.8844 & $3 \overline{24}$ & $\overline{45}$ & $4 \overline{5} 2$ & 49 & 39.5 \\
\hline Georgia* & 8.1 & 5.4 & 1.4977 & 462 & 43 & 525 & 51 & 13.6 \\
\hline Iowa & 6.3 & 5.5 & 0.7136 & 214 & 51 & 245 & 46 & $(9.8)$ \\
\hline Minnesota & 6.1 & 2.8 & 1.4240 & 320 & 42 & 384 & 40 & $(5.0)$ \\
\hline Colorado & 6.0 & 6.9 & 0.2714 & 118 & 19 & 187 & 23 & 58.4 \\
\hline Missouri* & 5.0 & 2.6 & 1.8481 & 444 & 49 & 439 & 40 & $\begin{array}{ll}(1.1) & (19.4)\end{array}$ \\
\hline Wisconsin* & 4.1 & 4.1 & 0.6213 & 501 & 57 & 551 & 54 & $10.0 \quad 5.3$ \\
\hline * Food industry is th & e second $\mathrm{I}$ & nost importan & stry but not the domin & industry. & $\mathrm{T}=\mathrm{TC}$ & al Manufac & ring & $\mathrm{F}=$ Food Manufacturing \\
\hline
\end{tabular}


Data presented in Table 2 on pollution abatement cost for the chemical industry region reveal that Alabama, Louisiana, Texas, and West Virginia were adversely affected resulting in a decline in manufacturing capital expenditures.

TABLE 2

EFFECT OF POLLUTION ABATEMENT COSTS ON CHEMICAL INDUSTRY REGION

\begin{tabular}{lcc}
\hline State & $\begin{array}{c}\text { Per Capita Capital Investments } \\
\text { \% Change 1977-1982 }\end{array}$ & $\begin{array}{c}\text { Pollution Abatement Expenses As A } \\
\text { \% of Industry Shipments 1977 }\end{array}$ \\
\cline { 2 - 3 } Alabama & $\mathbf{- 3 . 5 2}$ & 1.65 \\
Louisiana & $\mathbf{- 2 1 . 2 1}$ & 2.12 \\
New Jersey & 1.74 & .47 \\
South Carolina & .77 & .47 \\
Tennessee & 5.41 & 1.55 \\
Texas & $\mathbf{6 . 1 8}$ & .91 \\
Virginia & .56 & 1.22 \\
West Virginia & $\mathbf{3 . 4 5}$ & $\mathbf{3 . 1 0}$ \\
\hline
\end{tabular}

Table based upon data presented by Feiock and Rowland [1990:570].

Table 3 presents data for the manufacturing firms of the chemical industry region in which significant changes occurred. (Alabama and South Carolina were omitted since the chemical industry is the second most important industry but not the dominant industry in those states.) That data enable an assessment of the effect of pollution abatement cost in that region. It is assumed that (a) regions dominated by small firms would be negatively affected by pollution abatement cost and (b) regions dominated by large firms would be less affected owing to large firms' financial ability.

While relative pollution abatement cost was the second highest in Louisiana, the per capita capital investment in Louisiana was the most significantly adversely affected. The decline in per capita capital investments in Louisiana was 6 times greater than the decline in West Virginia and 3 times greater than that of Texas. Although West Virginia had the highest pollution abatement cost as a percentage of industry shipments, the adverse impact on capital investment was remarkably less severe than that of Louisiana. Although the relative pollution abatement cost in Texas was slightly less than one-third that of West Virginia, surprisingly the negative impact on Texas was almost twice as much as the impact in West Virginia. 


\begin{tabular}{|c|c|c|c|c|c|c|c|c|c|c|}
\hline LARGE AND & ALL I & $\begin{array}{r}\text { REGIO } \\
\text { RMS WI }\end{array}$ & $\begin{array}{l}\text { NAL FII } \\
\text { TH PLA }\end{array}$ & $\begin{array}{l}\text { TABLE } \\
\text { RM-TY } \\
\text { NTS EI }\end{array}$ & $\begin{array}{l}3 \\
\text { E DOM } \\
\text { IPLOYI }\end{array}$ & $\begin{array}{l}\text { IINANCI } \\
\text { ING 1,00! }\end{array}$ & OR M & RE EM & IPLOYEI & \\
\hline State & & Plants & $\frac{1960}{\frac{\text { Emps. }}{(000)}}$ & $\frac{\%}{\text { of } 3}$ & $\underline{\text { Plants }}$ & $\frac{1970}{\frac{\text { Emps. }}{(000)}}$ & $\frac{\%}{\text { of } 3}$ & $\underline{\text { Plants }}$ & $\frac{1980}{\frac{\text { Emps. }}{(000)}}$ & $\frac{\%}{\text { of } 3}$ \\
\hline $\begin{array}{l}\text { Tennessee } \\
\text { 1. } \\
\text { 2. Chemical Industry }\end{array}$ & $\begin{array}{l}\text { Large } \\
\text { Small } \\
\text { Total }\end{array}$ & $\begin{array}{l}19 \\
\underline{23} \\
42\end{array}$ & $\begin{array}{l}63 \\
\underline{36} \\
\underline{99} \\
\end{array}$ & $\frac{32.1}{12.7}$ & $\begin{array}{l}39 \\
29 \\
68 \\
\end{array}$ & $\begin{array}{r}104 \\
\frac{38}{142} \\
54 \\
\end{array}$ & $\frac{31.5}{12.0}$ & $\begin{array}{l}50 \\
\underline{17} \\
\underline{67}\end{array}$ & $\begin{array}{r}111 \\
24 \\
\frac{135}{52} \\
\end{array}$ & $\underline{27.5}$ \\
\hline 3. All Manufacturing & & & $\underline{308}$ & $\underline{100.0}$ & & $\underline{448}$ & $\underline{100.0}$ & & $\underline{491}$ & $\underline{100.0}$ \\
\hline $\begin{array}{l}\text { Texas } \\
\text { 1. } \\
\text { 2. Chemical Industry }\end{array}$ & $\begin{array}{l}\text { Large } \\
\text { Small } \\
\text { Total }\end{array}$ & $\begin{array}{l}27 \\
\underline{10} \\
\underline{37} \\
\end{array}$ & $\begin{array}{r}137 \\
20 \\
\underline{157} \\
40 \\
\end{array}$ & $\frac{32.2}{8.2}$ & $\begin{array}{l}55 \\
\underline{23} \\
\underline{78} \\
\end{array}$ & $\begin{array}{r}157 \\
\frac{31}{188} \\
54 \\
\end{array}$ & $\frac{26.0}{7.5}$ & $\begin{array}{l}78 \\
\underline{17} \\
95 \\
\end{array}$ & $\begin{array}{r}156 \\
\frac{19}{175} \\
\frac{73}{4} \\
\end{array}$ & $\frac{16.8}{7.0}$ \\
\hline 3. All Manufacturing & & & $\underline{486}$ & $\underline{100.0}$ & & $\underline{722}$ & $\underline{100.0}$ & & $\underline{1046}$ & $\underline{100.0}$ \\
\hline $\begin{array}{l}\text { 2. Chemical Industry } \\
\text { 3. All Manufacturing }\end{array}$ & $\begin{array}{l}\text { Large } \\
\text { Small } \\
\text { Total }\end{array}$ & $\begin{array}{l}20 \\
\underline{15} \\
\underline{35}\end{array}$ & $\begin{array}{l}59 \\
\underline{23} \\
\frac{82}{30} \\
\underline{273} \\
\end{array}$ & $\frac{\frac{30.0}{11.1}}{\underline{100.0}}$ & $\begin{array}{l}34 \\
\underline{26} \\
\underline{60}\end{array}$ & $\begin{array}{r}117 \\
\frac{39}{156} \\
\frac{38}{354} \\
\end{array}$ & $\frac{\frac{44.1}{10.7}}{\underline{100.0}}$ & $\begin{array}{l}42 \\
\underline{14} \\
\underline{56}\end{array}$ & $\begin{array}{r}88 \\
\frac{20}{108} \\
\frac{33}{418} \\
\end{array}$ & $\frac{25.9}{7.8}$ \\
\hline $\begin{array}{l}\text { Louisiana } \\
\text { 1. } \\
\text { 2. Chemical Industry } \\
\text { 3. All Manufacturing }\end{array}$ & $\begin{array}{l}\text { Large } \\
\text { Small } \\
\text { Total }\end{array}$ & $\begin{array}{r}14 \\
\frac{4}{18} \\
\end{array}$ & $\begin{array}{r}35 \\
\frac{8}{43} \\
\underline{16} \\
\underline{113} \\
\end{array}$ & $\frac{\frac{37.9}{13.9}}{\underline{100.0}}$ & $\begin{array}{r}18 \\
\frac{8}{26} \\
\underline{26}\end{array}$ & $\begin{array}{r}42 \\
\underline{11} \\
\underline{53} \\
\underline{22} \\
\underline{168} \\
\end{array}$ & $\frac{\frac{31.3}{13.3}}{\underline{100.0}}$ & $\begin{array}{r}19 \\
\underline{6} \\
\underline{25}\end{array}$ & $\begin{array}{r}42 \\
\frac{8}{50} \\
\underline{31} \\
\underline{209} \\
\end{array}$ & $\begin{array}{r}\frac{23.9}{15.0} \\
\underline{100.0} \\
\end{array}$ \\
\hline $\begin{array}{l}\text { 2. Chemical Industry } \\
\text { 3. All Manufacturing }\end{array}$ & $\begin{array}{l}\text { Large } \\
\text { Small } \\
\text { Total }\end{array}$ & $\begin{array}{r}65 \\
52 \\
117 \\
\end{array}$ & $\begin{array}{r}196 \\
\frac{75}{271} \\
\underline{81} \\
\underline{816}\end{array}$ & $\frac{\frac{33.2}{9.9}}{\underline{100.0}}$ & $\begin{array}{r}82 \\
27 \\
109 \\
\end{array}$ & $\begin{array}{r}223 \\
\frac{40}{263} \\
\underline{102} \\
\underline{859}\end{array}$ & $\frac{\frac{30.7}{11.9}}{\underline{100.0}}$ & $\begin{array}{r}83 \\
23 \\
106 \\
\end{array}$ & $\begin{array}{r}191 \\
\frac{31}{222} \\
\underline{96} \\
\underline{813}\end{array}$ & $\frac{27.3}{11.7}$ \\
\hline $\begin{array}{l}\text { 2. Chemical Industry } \\
\text { 3. All Manufacturing }\end{array}$ & $\begin{array}{l}\text { Large } \\
\text { Small } \\
\text { Total }\end{array}$ & $\begin{array}{l}14 \\
\underline{10} \\
\underline{24}\end{array}$ & $\begin{array}{r}43 \\
\frac{15}{58} \\
\underline{22} \\
\underline{117} \\
\end{array}$ & $\begin{array}{r}\frac{48.9}{19.0} \\
100.0 \\
\end{array}$ & $\begin{array}{r}24 \\
\frac{2}{26} \\
\end{array}$ & $\begin{array}{r}42 \\
\frac{3}{45} \\
\frac{23}{122} \\
\end{array}$ & $\frac{\frac{36.4}{18.7}}{100.0}$ & $\begin{array}{r}17 \\
\underline{3} \\
\underline{20} \\
\end{array}$ & $\begin{array}{r}36 \\
\frac{5}{41} \\
\underline{8} \\
\underline{115} \\
\end{array}$ & $\frac{\frac{35.6}{6.9}}{100.0}$ \\
\hline
\end{tabular}

The source for data on plants with 1,000 or more employees is Marketing Economics Key Plants. 
In 1970, West Virginia was a large firm-type dominated region. Hence, it comes as no surprise that in West Virginia, there was reduction in large firms (from 24 in 1970 to 17 in 1980) due to either plant closings or plant relocations to other regions due to pollution abatement cost.

For the HRG (group with high response to growth of the dominant industry), the data reveal a definite size effect of the pollution abatement cost in Texas. Tennessee and Virginia had positive capital investments. However, Texas, with large firms accounting for $82 \%$ of all firms, had a significant decline in per capital investment. For the LRG (group with low response to growth of the dominant industry), except for New Jersey, there is a size effect - a small firm effect in Louisiana, and a large firm effect in West Virginia. The reduction in importance of large firms in West Virginia is attributable to the relative magnitude of the pollution abatement cost. In West Virginia, the cost was approximately $2 \frac{1}{2}$ times that of Tennessee and $1 \frac{1}{2}$ half times that of Texas. In New Jersey the impact was relatively insignificant due to the fact that the pollution abatement cost was a mere $15.5 \%$ of the cost experienced in West Virginia.

Data in Table 4 on small firms, as a percent of large firms engaged in manufacturing, provide a vivid portrayal of the rather dramatic impact of the pollution abatement cost on small firms being the dominant firm-type of a region's manufacturing activities. As stated earlier, regions dominated by small firms would be more negatively affected by adverse regional conditions than regions dominated by large firms. The financial capabilities of large firms enable them to withstand adverse operating conditions better than smaller firms.

\section{TABLE 4 \\ REGIONAL FIRM-TYPE DOMINANCE \\ PLANTS AND EMPLOYEES: SMALL FIRMS AS A PERCENT OF LARGE FIRMS PLANTS EMPLOYING 1,000 OR MORE EMPLOYEES}

\begin{tabular}{|c|c|c|c|c|c|c|}
\hline \multirow[b]{2}{*}{$\underline{\text { State }}$} & \multicolumn{2}{|c|}{1960} & \multicolumn{2}{|c|}{1970} & \multicolumn{2}{|c|}{1980} \\
\hline & $\frac{\text { Plants }}{\%}$ & $\frac{\text { Emps. }}{\%}$ & $\frac{\text { Plants }}{\%}$ & $\frac{\text { Emps. }}{\%}$ & $\frac{\text { Plants }}{\%}$ & $\frac{\text { Emps. }}{\%}$ \\
\hline Tennessee & 121 & 57 & 74 & 36 & 34 & 22 \\
\hline New Jersey & 80 & 38 & 33 & 18 & 28 & 16 \\
\hline Virginia & 75 & 39 & 76 & 33 & 33 & 23 \\
\hline West Virginia & 71 & 35 & 8 & 7 & 18 & 14 \\
\hline Texas & 40 & 15 & 40 & 20 & 22 & 12 \\
\hline Louisiana & 29 & 23 & 44 & 26 & 31 & 19 \\
\hline
\end{tabular}




\section{EXPLANATION OF VARIATIONS AS SUGGESTED BY THE HYPOTHESIS}

Data in Table 1 revealed regional variation in responsiveness to growth of the dominant industry. Since manufacturing mix may be a causal factor, it is necessary to look at states with significantly different total manufacturing value added growth rates in comparison to the growth rates of the dominant industry to determine if mix can explain the variation.

Both improving and deteriorating conditions that can be ascribed to firm-type dominance are disclosed in Table 3. The rank correlation for the growth rates for total manufacturing value added and chemical manufacturing data is .31 , which is statistically insignificant. No significant correlation existed among the paired observations. Since manufacturing mix is not a sufficient condition for similarity in intra-region manufacturing linkage, it is argued that regional manufacturing growth is explainable by the firm-type dominance of regional manufacturing output.

Data in Table 5 provide further evidence to support the hypothesis; that is, variation (high versus low responsiveness) in regional performance may be explained in terms of the non-local (N/F) firm versus local firm dominance in a region (state). In the classification of firms as being a local or non-local firm, when in the few instances that the location of a firm's headquarters could not be determined from the available data, the firm was classified as non-local. This aspect of the classification process most likely leads to an understatement of the number of local firms.

The 1980 data on local versus non-local headquarters of the regional firms provide insight on the impact of firm-type dominance. Since Texas, New Jersey, Louisiana, and Tennessee (ranked third, fifth, seventh, and ninth respectively among 38 states based upon cumulative manufacturing capital expenditures for the period: 1960-1971[Salvary 1977:186]) are capital abundant states (states that experienced large amounts of financial capital flows), the lackadaisical responsiveness to the growth of the dominant industry (the low elasticity evidenced) in Louisiana and in New Jersey may be accounted for as noted in Table 6. In Panel C of Table 5, the four states were N/F firm-type dominated. Yet the responses of the supporting industries to the growth of the dominant industry (as reflected in the total manufacturing growth in those regions) were significantly different to those of Texas and Tennessee. 


\begin{tabular}{|c|c|c|c|c|c|c|c|}
\hline \multicolumn{8}{|c|}{$\begin{array}{c}\text { TABLE } 5 \\
\text { REGIONAL FIRM TYPE DOMINANCE } \\
\text { LOCAL VERSUS NONLOCAL FIRMS MANUFACTURING PLANTS } \\
(\% \text { of Plants Owned by Local Firms to Total Plants })\end{array}$} \\
\hline Panel A: 1960 & $\underline{\text { All Firms }}$ & \multicolumn{3}{|c|}{ Local Firms } & \multicolumn{3}{|c|}{ Non-local Firms } \\
\hline State & Total Plants & Total & Large & Small & Total & Large & $\underline{\text { Small }}$ \\
\hline$\overline{\text { New Jersey }}$ & 117 & $39 \overline{(33.3 \%)}$ & 8 & 31 & $\overline{78}$ & 57 & 21 \\
\hline Tennessee & 42 & $11(26.2 \%)$ & 0 & 11 & 31 & 19 & 12 \\
\hline Texas & 37 & $10(27.0 \%)$ & 5 & 5 & 27 & 22 & 5 \\
\hline Virginia & 35 & $12(34.3 \%)$ & 3 & 9 & 23 & 17 & 6 \\
\hline West Virginia & 24 & $3(12.5 \%)$ & 2 & 1 & 21 & 12 & 9 \\
\hline Louisiana & 18 & $1(5.5 \%)$ & 0 & 1 & 17 & 14 & 3 \\
\hline Panel B: 1970 & $\underline{\text { All Firms }}$ & \multicolumn{3}{|c|}{ Local Firms } & \multicolumn{3}{|c|}{ Non-local Firms } \\
\hline State & Total Plants & Total & Large & $\underline{\text { Small }}$ & Total & Large & $\underline{\text { Small }}$ \\
\hline$\overline{\text { New Jersey }}$ & 109 & $34 \overline{(31.1 \%)}$ & 19 & 15 & 775 & 63 & 12 \\
\hline Texas & 78 & $27(34.6 \%)$ & 12 & 15 & 51 & 43 & 8 \\
\hline Tennessee & 68 & $16(23.5 \%)$ & 3 & 13 & 52 & 36 & 16 \\
\hline Virginia & 60 & $16(26.7 \%)$ & 5 & 11 & 44 & 29 & 15 \\
\hline Louisiana & 26 & $4(15.4 \%)$ & 1 & 3 & 22 & 18 & 4 \\
\hline West Virginia & 26 & $0(0.0 \%)$ & 0 & 0 & 26 & 24 & 2 \\
\hline Panel C: 1980 & $\underline{\text { All Firms }}$ & \multicolumn{3}{|c|}{ Local Firms } & \multicolumn{3}{|c|}{ Non-local Firms } \\
\hline State & Total Plants & Total & Large & $\underline{\text { Small }}$ & Total & Large & Small \\
\hline$\overline{\text { New Jersey }}$ & 106 & $40 \overline{(37.8 \%)}$ & 31 & 9 & $\overline{66}$ & 52 & 14 \\
\hline Texas & 95 & $35(36.8 \%)$ & 25 & 10 & 60 & 53 & 7 \\
\hline Tennessee & 67 & $13(20.0 \%)$ & 5 & 8 & 54 & 45 & 9 \\
\hline Virginia & 56 & $18(32.1 \%)$ & 10 & 8 & 38 & 32 & 6 \\
\hline Louisiana & 25 & $5(20.0 \%)$ & 3 & 2 & 20 & 16 & 4 \\
\hline West Virginia & 20 & $1(5.0 \%)$ & 1 & $\mathbf{0}$ & 19 & 16 & 3 \\
\hline
\end{tabular}

TABLE 6

DISSIMILAR RESPONSES OF LARGE LOCAL AND N/F FIRM-TYPE DOMINANCE

\begin{tabular}{|c|c|c|c|c|c|c|c|}
\hline \multirow[b]{2}{*}{ State } & \multicolumn{2}{|c|}{$\frac{\text { Ten Year Cumulative }}{\text { Capital Expenditures }}$} & \multirow{2}{*}{$\frac{\frac{\text { Elasticity/ }}{\text { Response }}}{\frac{\text { Coefficient }}{\%}}$} & \multicolumn{2}{|c|}{$\frac{\frac{\text { Growth Rate* of }}{\text { Total Manufacturing }}}{\underline{\text { Value Added }}}$} & \multicolumn{2}{|c|}{$\frac{\text { Growth Rate* of }}{\frac{\text { Total Capital }}{\underline{\text { Expenditures }}}}$} \\
\hline & $\$ 000,000$ & $\underline{\text { Rank }}$ & & $\%$ & $\underline{\text { Rank }}$ & $\%$ & $\underline{\text { Rank }}$ \\
\hline$\overline{\text { Texas }}$ & 10,500 & 3 &.$\overline{6621}$ & 7.8 & 3 & $\overline{14.9}$ & 3 \\
\hline New Jersey & 6,718 & 5 & .3654 & 3.3 & 9 & 8.6 & 9 \\
\hline Louisiana & 3,810 & 7 & .3871 & 7.1 & 4 & 17.2 & 1 \\
\hline Tennessee & 3,600 & 9 & .8816 & 8.5 & 1 & 14.1 & 4 \\
\hline
\end{tabular}

Source: Response Coefficient in Table 1 above - Remainder from Salvary [1977:186 - Table 82]. 
Since manufacturing activities in Louisiana and New Jersey are dominated by large NF and local firms, the low elasticity evidenced would suggest that the leakage out of those regions is due to the failure of capital to flow to the firms in the supportive industries to enable them to expand (respond) pari-passu with the warranted growth fostered by the growth of the dominant industry. In particular, the low elasticity evidenced reveals that the leakage out of Louisiana is due primarily to horrendous pollution abatement cost. Consequently, the large (N/F and local) firms in Louisiana's supportive industries have simply relocated manufacturing operations to other regions. Increased demand brought about by the dominant industry is satisfied by the N/F firms either by expanding output of the supportive industries at branch plants in other regions to obtain internal economies of scale or by the construction of new plants in totally new regions. ${ }^{4}$

Another factor to be considered is the significant impact of foreign direct investment in US manufacturing. As noted by Coughlin [1992:17] "Foreign Direct Investment in the United States increased more than eleven-fold between 1977 and 1990." Table 7 [Coughlin 1992:17] provides data for 1980 and 1990 during which time the growth was five times. In that period 380 new foreign-owned plants were established in the US - 239 in the three industry regions: 102 - chemical industry region, 87 - electrical industry region, and 50 - food industry region. 76 of the 102 plants are located in states in which the chemical industry is the dominant industry-Tennessee 20, Texas 27, Virginia 17, New Jersey 7, Louisiana 4, and West Virginia 1; and the remaining 26 plants are located in states in which the chemical industry is not the dominant but the second most important industry, 18 in South Carolina and 8 in Alabama.

\section{TABLE 7}

FOREIGN DIRECT INVESTMENT IN THE UNITED STATES BY INDUSTRY

(Dollar Amounts in Billions)

\begin{tabular}{|c|c|c|c|c|}
\hline \multirow[b]{2}{*}{ Industry } & \multicolumn{2}{|c|}{1980} & \multicolumn{2}{|c|}{1990} \\
\hline & Level \$ & $\underline{\text { Share } \%}$ & Level \$ & Share \% \\
\hline$\overline{\text { Manufacturing }}$ & 33.0 & 39.8 & $\overline{160.0}$ & 39.6 \\
\hline All Other Industries & 50.0 & 60.2 & 343.7 & 60.4 \\
\hline Total & $\overline{83.0}$ & $\overline{100.0}$ & 403.7 & $\overline{100.0}$ \\
\hline
\end{tabular}

Table 8 provides the changes in manufacturing for 1987-1996 as compared to $1960-1971$. The impact of foreign investment is readily noticeable in West Virginia. 


TABLE 8
REGION AND INDUSTRY SPECIFIC MANUFACTURING VALUE ADDED EXPONENTIAL GROWTH
RATES AND MANUFACTURING CAPITAL EXPENDITURES EXPONENTIAL GROWTH RATES
FOR THE PERIODS 1960-1971 AND 1987-1996

\begin{tabular}{|c|c|c|c|c|c|c|}
\hline \multicolumn{7}{|c|}{ PANEL A: CHEMICAL INDUSTRY REGION } \\
\hline \multirow[t]{2}{*}{$\underline{\text { State/Region }}$} & $\underline{\text { TMVA }}$ & $\underline{\text { CMVA }}$ & $\underline{\text { TMVA }}$ & $\underline{\text { CMVA }}$ & $\underline{\text { TMCE }}$ & $\underline{\mathrm{CMCE}}$ \\
\hline & $\underline{1960-1971}$ & $\underline{1960-1971}$ & $\underline{1987-1996}$ & $\underline{1987-1996}$ & $\underline{1987-1996}$ & $\underline{1987-1996}$ \\
\hline Tennessee & 8.5 & 9.3 & $\underline{5.8}$ & $\underline{3.3}$ & 4.0 & 1.9 \\
\hline Texas & 7.8 & 9.3 & $\underline{6.1}$ & $\underline{3.2}$ & 9.3 & 7.4 \\
\hline Alabama* & 7.6 & 16.5 & $\overline{4.7}$ & $\overline{9.0}$ & 5.3 & 9.3 \\
\hline South Carolina* & 7.6 & 10.6 & $\underline{6.2}$ & $\underline{7.9}$ & 4.7 & 7.6 \\
\hline Louisiana & 7.1 & 13.3 & $\overline{4.3}$ & 3.5 & 7.0 & 6.9 \\
\hline Virginia & 5.9 & 6.5 & $\overline{5.1}$ & $\overline{4.0}$ & 6.1 & 5.3 \\
\hline New Jersey & 3.3 & 9.7 & $\underline{1.5}$ & 1.9 & 0.8 & 0.5 \\
\hline West Virginia & 2.8 & 5.0 & 5.2 & 8.1 & 4.4 & 5.1 \\
\hline \multicolumn{7}{|c|}{$\begin{array}{l}\text { *Chemical industry is second most important industry but not the dominant industry. TM= Total Manufacturing CM= Chemical Manufacturing } \\
\text { PANEL B: ELECTRICAL INDUSTRY REGION }\end{array}$} \\
\hline \multirow[t]{2}{*}{ State/Region } & $\underline{\text { TMVA }}$ & EMVA & TMVA & $\underline{\text { EMVA }}$ & $\underline{\text { TMCE }}$ & EMCE \\
\hline & $19 \overline{60-1971}$ & $\overline{1960-1971}$ & $19 \overline{987-1996}$ & $1987-1996$ & $19 \overline{87-1996}$ & $1 \overline{987-1996}$ \\
\hline Kentucky* & 8.3 & 14.1 & $\underline{17.3}$ & (1.1) & 8.1 & 6.8 \\
\hline California* & 5.2 & 9.5 & $\overline{3.5}$ & 9.2 & 5.5 & 12.1 \\
\hline New Hampshire & 4.8 & 9.5 & 4.2 & 13.5 & 4.4 & 8.8 \\
\hline Indiana & 4.8 & 8.7 & 5.3 & 1.8 & 3.5 & 1.3 \\
\hline Illinois* & 4.3 & 6.5 & 4.6 & 7.3 & 5.4 & 6.8 \\
\hline Connecticut* & 3.6 & 5.4 & $\overline{1.2}$ & 2.0 & 3.4 & 7.1 \\
\hline Massachusetts & 2.7 & 5.5 & $\overline{2.4}$ & $\overline{5.0}$ & 3.9 & 4.6 \\
\hline \multicolumn{7}{|c|}{$\begin{array}{l}\text { *Electrical industry is second most important industry but not the dominant industry. TM= Total Manufacturing EM= Electrical Manufacturing } \\
\text { PANEL C: FOOD INDUSTRY RERION }\end{array}$} \\
\hline \multirow[t]{2}{*}{$\underline{\text { State/Region }}$} & TMVA & FMVA & TMVA & FMVA & TMCE & FMCE \\
\hline & $1960-1971$ & $1960-1971$ & $1987-1996$ & $1987-1996$ & $1987-1996$ & $1987-1996$ \\
\hline Florida & 9.1 & 10.2 & 4.1 & 2.7 & 3.2 & 1.9 \\
\hline Georgia* & 8.1 & 5.4 & $\underline{5.2}$ & $\underline{7.5}$ & 4.4 & 8.8 \\
\hline Iowa & 6.3 & 5.5 & $\overline{6.7}$ & $\overline{6.2}$ & 9.4 & 6.6 \\
\hline Minnesota & 6.1 & 2.8 & $\underline{4.3}$ & $\underline{5.6}$ & 5.4 & 9.5 \\
\hline Colorado & 6.0 & 6.9 & $\overline{5.7}$ & $\overline{5.5}$ & 10.0 & 3.3 \\
\hline Missouri* & 5.0 & 2.6 & $\underline{4.6}$ & 7.4 & 7.4 & 6.2 \\
\hline Wisconsin* & 4.1 & 4.1 & $\underline{6.0}$ & $\underline{3.9}$ & 7.4 & 7.8 \\
\hline
\end{tabular}

* Food industry is the second most important industry but not the dominant industry. TM= Total Manufacturing FM= Food Manufacturing

In the chemical industry region, based on ranking in terms of Share of Plants/Gross State Product [Coughlin and Segev 2000:Table 1], South Carolina (rank \#2), Tennessee (rank \#4), and Virginia (rank \#10) benefited immensely in that order from new foreign plants. Texas (rank \#18) 
also benefited significantly but to a lesser extent than the three states mentioned above. This finding is not surprising as Coughlin [1992:27] noted: the chemical industry is controlled by foreign firms. In addition, other states belonging to other industry regions with very high rankings were significant beneficiaries. In the electrical industry region, Kentucky, in which chemical manufacturing is fourth in importance, was ranked \#1, and Indiana, in which chemical manufacturing is also fourth in importance, was ranked \#7. In the food industry region, Iowa, in which chemical manufacturing is fourth in importance, was ranked \#8, and Georgia, in which chemical manufacturing is third in importance, was ranked \#9.

Apart from a decline in manufacturing employment in the national economy, the data underlined and in script in Table 8 are suggestive of the significant structural shift during the 1980s in manufacturing across states and the composition of manufacturing within states. This combination of occurrence can be attributed to both international trade as noted by Bauer and Eberts [1990] and direct foreign investment in US manufacturing as documented by Coughlin and Segev [2000] and Coughlin [1992]

\section{SUMMARY}

This paper suggests that regions can be classified by firm-type (national/foreign or local) dominance of manufacturing output. This distinction is important for policy analysis, since two critical variables (capital availability and location decision) can be identified with regional output modeling. The impact on a particular region of these two variables depends upon the firm-type dominance of that region's manufacturing output. This paper draws upon the dominant industry model which has established that: (1) in any given region, there is a dominant industry (the industry which is the driving force of the region), and (2) the manufacturing growth of a region is linked to the growth of the region's dominant industry.

An industry region construct (a region in economic space consisting of state regions having the same dominant industry) is used to enable the observation of the varying response patterns to the dominant industry. Leakage of manufacturing output from a state region, due to the inability of a region's supportive industries to respond to the growth of the dominant industry, can be explained by the firm-type dominance hypothesis. Elasticity coefficients of the state 
regions within an industry region are utilized to measure a region's responsiveness to the dominant industry. The elasticity coefficients (responsiveness) of the individual state regions' manufacturing output to growth of the region's dominant industry can be used by regional policymakers to assess the feasibility of manufacturing diversification policies a la portfolio theory. Low responsiveness of supportive industries producing regional shifts in manufacturing is identifiable with: (a) the unavailability of capital due to local firm-type dominance or (b) the out of region location decision of the supportive industries' expansion due to national/foreign firm-type dominance.

\section{LIMITATIONS AND CONCLUSION}

Given the limited amount of data employed in testing the hypothesis, the results only provide some preliminary findings, which are subject to further verification. This study did not attempt to assess the impact of foreign imports in the displacement of domestic output, thereby decreasing domestic production. The impact of this variable has to be given full consideration in policy analysis and development. Future research should focus on: (a) calibrating the model with spatial data by expanding the number of industry regions, (b) changing the definition of large firm size from the $\$ 100$ million to $\$ 1$ billion in sales, (c) assessing the regional displacement impact of foreign imports, and (c) subjecting the hypothesis to rigorous statistical testing.

The preliminary findings suggest that, assuming portfolio theory is feasible, firm-type dominance should be considered when implementing a diversification policy. Since there are far more important determinants of industrial location than tax-breaks, a region should not expect that a tax-break will induce firms to locate future manufacturing expansion in that region. Owing to their friendly manufacturing environments - infrastructure, research facilities, trained labour force, educational facilities, and other public goods - many state-regions have benefited from foreign direct investment. If an appropriate operating environment is established in a region, N/F firms will invite themselves into the region. Apparently analysis utilizing the Firm-Type Dominance/Industry Region Model could provide a sound basis for understanding regional manufacturing problems and aid in the formulation of relevant fiscal policies at the regional and federal levels of government. 


\section{ENDNOTES}

1 In one study of the influences on patterns of industrial location, McHone [1984] recognized the limitation of the SMSA and the significance of the state as the region in this setting. Accordingly, McHone [1984] limited his observations to SMSAs that straddled more than one state to determine the impact of incentives on locational decisions. hUallachain [1989:1205] empirical study focused on economies of scale and as such justifies the use of the metropolitan statistical area as "the appropriate geographical scale for testing models of growth ...."

2 Both Richardson [1978] and Gerking and Isserman [1981:465] are advocates of the integrated approach.

3 Overlapping concentric zones, which are comprised of a few contiguous regions and influence transportation-dependent industry location, are created by the transportation networks.

4 According to Moriarty [1991:1576], in $198276 \%$ of the US manufacturing workforce was employed by multi-plant firms; whereas in 1947 the portion employed by multi-plant firms was $56 \%$.

\section{BIBLIOGRAPHY}

Bauer, Paul W. and Eberts, Randall W. (1990) "Exports and Regional Economic Restructuring." Journal of Regional Analysis and Policy (20.No1).

Brittain, John A. (1966) Corporate Dividend Policy. Washington, D.C.: Brookings Institution.

Bremmer, Dale S. and Kesselring, Randall G. (1993) "The Determinants of Regional Manufacturing Investment: A Simultaneous Equations Approach.” Journal of Regional and Policy Analysis 23 No.2.

Burrows, James C.; Metcalf, Charles E.; and Kaler, John B. (1971) Industrial Location in the United States. Lexington, Massachusetts: D. C. Heath and Company.

Business Week. (1976) “The Second War Between the States.” Business Week (May 17).

Carlton, Dennis W. (1983) "The Location and Employment Choices of New Firms: An Econometric Model with Discrete and Continuous Endogenous Variables." Review of Economics and Statistics (August).

Committee of New England of the National Planning Association. (1954) The Economic State of New England. New Haven: Yale University Press.

Conroy, Michael E. (1975) Regional Economic Growth: Diversification and Control. New York; Washington; London: Praeger Publisher. 
Cottle, Sidney and Whitman, Tate. (1959) Corporate Earning Power and Market Valuation 1935-1955. Durham, North Carolina: Duke University Press.

Coughlin, Cletus C. (1992) "Foreign-owned companies in the United States: malign or benign?" Federal Reserve Bank of St. Louis Review (May 1).

Coughlin, Cletus and Segev, Eran. (2000) "Location Determinants of New Foreign-Owned Manufacturing Plants" Journal of Regional Science (V.40 No.2).

Donaldson, Gordon. (1961) Corporate Debt Capacity. Boston: Harvard University Press.

Drobovolsky, Sergei P. (1951) Corporate Income Retention 1915-1943. New York: National Bureau of Economic Research, Inc.

Dun \& Bradstreet. (1987) Million Dollar Directory. Parsippany, New Jersey: Dun \& Bradstreet. . (1980) Million Dollar Directory. Parsippany, New Jersey: Dun \& Bradstreet. . (1971) Million Dollar Directory. Parsippany, New Jersey: Dun \& Bradstreet. . (1964) Million Dollar Directory. Parsippany, New Jersey: Dun \& Bradstreet.

Engerman, S. "Regional Aspects of Stabilization Policy." (1965) Essays in Fiscal Federalism. Edited by R.A. Musgrave. The Brookings Institution as cited in Regional Analysis. Edited by L. Needleman. Middlesex, England: Penguin Books, Ltd., 1968.

Ersenkal, Caryl R. and Dillman, B. L. (1984) "The Product Cycle and Shifts in the Location of Manufacturing." Journal of Regional and Policy Analysis (14 No.1):30-39.

Feiock, Richard and Rowland, C. K. (1990) "Environmental Regulation and Economic Developmen: The Movement of Chemical Production among States." Western Political Quarterly (September): 561-576.

Fotheringham, A. Stewart. (1985) "Modeling Firms: Locational Choices and Core-Periphery Growth." Growth and Change 16: 13-16.

Gerking, Shelby D. and Isserman, Andrew M. (1981) "Bifurcation and the Time Pattern of Impacts in the Economic Base Model." Journal of Regional Science 21:451-467.

Grose, Andrew P. (1993) "The Pros and Cons of Investment Incentives: How Do You Know You Get What You Pay For?" Spectrum (Summer): 21-28.

Hamberg, Daniel. (1971) Models of Economic Growth. New York; London: Harper \& Row. (1956) Economic Growth and Instability. New York: W.W. Norton \& Company Inc.

Helms, L. Jay. (1985) "The Effect of State and Local Taxes on Economic Growth: A Time Series-Cross Section Approach." Review of Economics and Statistics (November). 
hUallachain, B. O. (1990) "The Location of US Manufacturing: Some Empirical Evidence on Recent Geographical Shifts." Environment and Planning A. 22:1205-1222.

Kalecki, M. (1954) Theory of Economic Dynamics. London: George Allen \& Unwin.

Lintner, John. (1949) Corporate Profits in Perspective. Washington, D.C.: American Enterprise Association, Inc.

Marketing Economics Institute. (1960) Key Plants Manufacturing Marketing Directory: 40,000 Plants with 100 or more Employees. New York: Marketing Economics Institute. (1969/1970) Key Plants Manufacturing Marketing Directory. New York: Marketing Economics Institute.

. (1979/1980) Key Plants Manufacturing Marketing Directory. New York: Marketing Economics Institute.

McHone, W. Warren. (1984) "State Industrial Development Incentives and Employment Growth in Multistate SMSAs." Growth and Change 15:8-15.

Meyer, John R. and Kuh, Edwin. (1959) The Investment Decision - An Empirical Study. Cambridge, Massachusetts: Harvard University Press.

Moriarty, B. M. (1991) "Urban Systems, Industrial Restructuring, and the Spatial-Temporal Diffusion of Manufacturing Employment." Environment and Planning A 23:1571-1588.

Perroux, Francois. "Note on the Concept of 'Growth Poles' ". (1955) (Translated from French: "Note sure la Notion de'pole de croissance." Economie Appliquee as cited in Regional Economics: Theory and Practice. Edited by David L. McKee, Robert D. Dean and William Leahy. New York: The Free Press. London: Collier Macmillan Limited, 1970.

Richardson, Harry W. (1978) "The State of Regional Economics: A Survey Article." International Regional Science Review (Fall).

Rosengren, Eric S. (1990) "How Diversified is New England?" New England Economic Review (Nov./Dec.).

Rumelt, Richard P. (1974) Strategy, Structure and Economic Performance. Cambridge, Massachusetts: Harvard University Press.

Salvary, Stanley C. W. (2004) "The Neoclassical Model, Corporate Retained Earnings, and the Regional Flows of Financial Capital.” EconPapers. RePEc:wpa:wuwpur:0410007.

- (1987 "An Empirical Test of the Dominant Industry Hypothesis: Some Preliminary Evidence." Regional Science Perspectives (17:1).

. (1977) Regional Manufacturing Economic Growth: An Empirical Analysis of 
the Impact of the Dominant Industry Hypothesis. Doctoral Dissertation. New York University.

Sherman, Howard J. (1968) Profits in the United States. New York: Cornell University Press.

Stafford, Howard A. (1991) "Manufacturing Plant Closure Selections within Firms." Annals of the Association of the American Geographers (81-1: 51-65).

Steinnes, Donald N. (1984) "Business Climate, Tax Incentives, and Regional Economic Development." Growth and Change (15:38-57).

U.S. Congress, House, Committee on Interstate and Foreign Commerce. Institutional Investor Study, Report of the Securities and Exchange Commission. Vol. 4. H. Doc. 92-64, Part 4, 92nd Congress, 1st sess., 1971.

\section{Copyright $@ 2007$}

